\title{
A century of morphological variation in Cyprinidae fishes
}

\author{
Stephen J. Jacquemin ${ }^{1 *}$ and Mark Pyron ${ }^{2}$
}

\begin{abstract}
Background: Aquatic habitats have been altered over the past century due to a variety of anthropogenic influences. Ecomorphology is an area of aquatic ecology that can both directly and indirectly assess the effects of habitat alterations on organisms. However, few studies have explored long term trends in morphological variation. Long term changes in morphology can potentially impact niche and ultimately contribute to organismal success and the ecosystem. Therefore, in this study we assessed long term morphological variation with body size, sex, time, and hydrology using museum collections of five species of Cyprinidae (Minnows) from lentic and lotic systems over the past 100 years to gain insight into long term patterns in morphology.

Results: Variation in Cyprinidae morphology tended to relate to: body size-indicating strong allometric growth patterns with robustness of larger individuals; sex-indicating a level of fecundity selection for deeper bodies in females compared with males; and year-indirectly suggesting responses to habitat changes over the past century. In lotic ecosystems, Cyprinidae morphology tended to be more fusiform in conjunction with lower mean annual discharge or higher variation in discharge. In lentic ecosystems, change in morphology was observed but no historic habitat variables were available to discern potential mechanisms. Interestingly, not all species responded in the same magnitude or directionality.
\end{abstract}

Conclusions: Long term changes in morphological variation provide a link to exploring functional relationships between taxa and their environment and have implications for understanding ecosystem attributes, community assembly patterns, and conservation.

Keywords: Geometric morphometrics, North American fish morphology, Long term morphology, Global change, Long term hydrological variation, Habitat alteration, Contemporary evolution

\section{Background}

Freshwater ecosystems have become increasingly altered over the past several centuries through a variety of anthropogenic changes to watersheds that have resulted in degraded physical habitats, declines in water quality, and disruption of flow regimes on both local and regional scales [1-3]. Understanding the potential effects of widespread ecosystem alterations on biota and their implications have become primary conservation issues. Central to understanding the impact of changes to habitats over the past century are species-environment relationships

\footnotetext{
*Correspondence: stephen.jacquemin@wright.edu

${ }^{1}$ Department of Biological Sciences, Dwyer Hall, Wright State UniversityLake Campus, Celina, OH 45822, USA

Full list of author information is available at the end of the article
}

[4], particularly how organismal morphology may play a part in the functional role of an individual in an ecosystem. These larger scale relationships between morphology and environment can improve predictability and understanding of potential assemblage and ecosystem level attributes [5-7]. However, few studies have used long term collections or datasets to assess what variables may relate to variation in morphology over a long term period. Therefore, the purpose of this study was to apply an exploratory technique incorporating a suite of tests to identify potential morphological covariates in fishes over the past century.

Freshwater fishes display a range of morphological adaptations across a wide variety of physiological states and environmental conditions as a result of genetic 
divergence and/or phenotypic plasticity $[5,8,9]$. Physiological influences are frequently identified as morphological relationships with body size (allometry), diet (feeding performance), and sex (sexual selection) while plasticity tends to respond to local environmental variation related to niche patterns of resource utilization, behavior, and/ or habitat use [5, 8-11]. Typically, as fishes move through their ontogeny there are allometric trends in shape [12, 13]. These allometric trajectories can follow different patterns in individual species but are often shown to relate to body depth and robustness of an individual [12, 14]. These changes with ontogeny can be further explored in light of sexual dimorphism as individuals reach sexual maturity, whereby females tend to take on a deeper body shape compared with males. In addition to body size and sex, diet and resource utilization affect morphology, whereby particular dietary items can induce morphological change within or among populations [8]. Lastly, all of these factors can be complicated by environmental variation with phenotypic plasticity. For example, Langerhans et al. [15] identified increasingly fusiform body shapes of Neotropical fishes in main channel habitats compared to lower flow lagoon habitats coinciding with variation in flow conditions. Similarly, Haas et al. [16] found that deeper-bodied Cyprinella (Cyprinidae) are indicative of reservoir compared to riverine habitats. More recently, Dugas et al. [17] studied body streamlining (fusiform) with river velocity in Cyprinella whipplei males and did not find positive correlations but did suggest that deeper body shape may provide increased maneuverability during male-male interactions during combat and that this may be of greater importance than increased streamlining. Regardless, while these field documented effects of local habitats influence on morphology are varied they have been reproduced and manipulated in laboratory experiments [18]. Yet, while these documented trends in physiology and plasticity exist in contemporary studies, it is impossible to quantify everything that drives body shape trends. Further challenging is dealing with questions of long term organismal changes [19] where a paucity of biological specimens and/or environmental information impedes long term morphological studies.

Natural history museum collections may provide the best opportunity to observe and test for some of these long term changes in morphological traits of taxa concurrent with habitat variation. Biological and environmental data are most readily available in the form of historical museum collections of preserved fish specimens (potentially from 1880 to present $[20,21])$ and associated specimen lot description tags. For example, a recent study utilizing museum collection lots and data identified rapid change in the morphology of a stream fish in the decades that followed construction of a series of reservoirs in the United States [19]. And while these long term collections that are available do not encompass all taxa from all locales, these resources can help facilitate ecological hypotheses across a large temporal scale of taxa, assemblages, and ecosystems [22].

Specific to long term morphology of fishes, morphological variation that is correlated with physiological parameters such as body size or sex can be directly assessed from measurement or dissection of preserved specimens and analyzed by collection year. These types of studies become more accessible compared with those invoking plasticity or immigration trends with environmental change as local habitat conditions at the time of these long term collections may not be as readily apparent with variation in detailed collection records. One interesting solution to sparse habitat records is to use time as an indirect proxy for habitat change and follow up with historical climate change data of precipitation, temperature, landscape development trends, or with direct records such as flow regime (daily hydrology data available for many streams from 1900 to present-http:// waterdata.usgs.gov/).

Global climate change models were particularly helpful in facilitating our understanding of ecosystem responses to changes in precipitation, temperature, and human landscape impacts [23]. Of particular interest are changes in flow regime, as flow regime provides an overarching influence on aquatic ecosystems [1], either directly in streams or indirectly for lakes and can serve as a proxy for habitat [24]. The effects of flow regime changes on freshwater fishes have been documented in numerous taxa and communities (reviewed by Poff and Zimmerman [25]) and provide inferences into population responses to environmental alterations [16, 26]. Alterations to flow regimes have been linked to physical habitat homogenization and degradation [27], changes in aquatic assemblages [28], reductions in ecological community resilience [29], changes in assemblage functional attributes [30, 31], changes to structure of assemblage level morphological diversity [32], and long term hydrology effects on contemporary assemblages [33]. However, fewer studies have linked long term changes in freshwater fish taxa with variation in environment [34].

Despite numerous studies that have established relationships between morphology and suites of abiotic and biotic factors, the patterns that emerge from long term tests for these relationships are virtually unknown. Therefore, the objective of this study was to describe shape variation for five species in the family Cyprinidae (Minnows) relative to body size, sex, time, and environment (e.g. hydrology where available) over 100 years using long term collections from both lotic and lentic sites. We predicted that long term collections would exhibit 
morphological signal as a result of both physiological and environmental influences. Ultimately, ecomorphological perspectives may improve our understanding of shape variability while providing potential links with functional performance in changing ecosystems.

\section{Methods}

\section{Fish and morphology}

Museum collections of five species of Cyprinidae from the Illinois Natural History Survey (INHS) were selected based on long term repeated collections of approximately ten individuals representing both males and females from each collection effort. Species found to meet this criteria were Striped Shiner (Luxilus chrysocephalus), Redfin Shiner (Lythrurus umbratilis), Emerald Shiner (Notropis atherinoides), Sand Shiner (Notropis stramineus), and Bluntnose Minnow (Pimephales notatus) (see Appendix for INHS catalog numbers). Collection dates ranged from 1899 to 2006. All collections were in Illinois, USA (Fig. 1; Table 2) and included long term biological monitoring sites on the Sangamon River (Champaign/McLean Co.), Mackinaw River (Tazewell/Woodford Co.), Little Vermillion River (Vermillion Co.), Salt Creek (Logan/DeWitt Co.), Illinois River (LaSalle/Grundy Co.), and Lake Michigan (Cook Co.). Individuals were photographed using a tripod-mounted digital Nikon D70 camera (Nikkor AF-S DX Macro Zoom Lens) against a grid display for scale reference. Images were digitized by one person (SJJ) using a series of 11 predefined landmarks [14] (see Fig. 2 for landmark placement and description) within the software

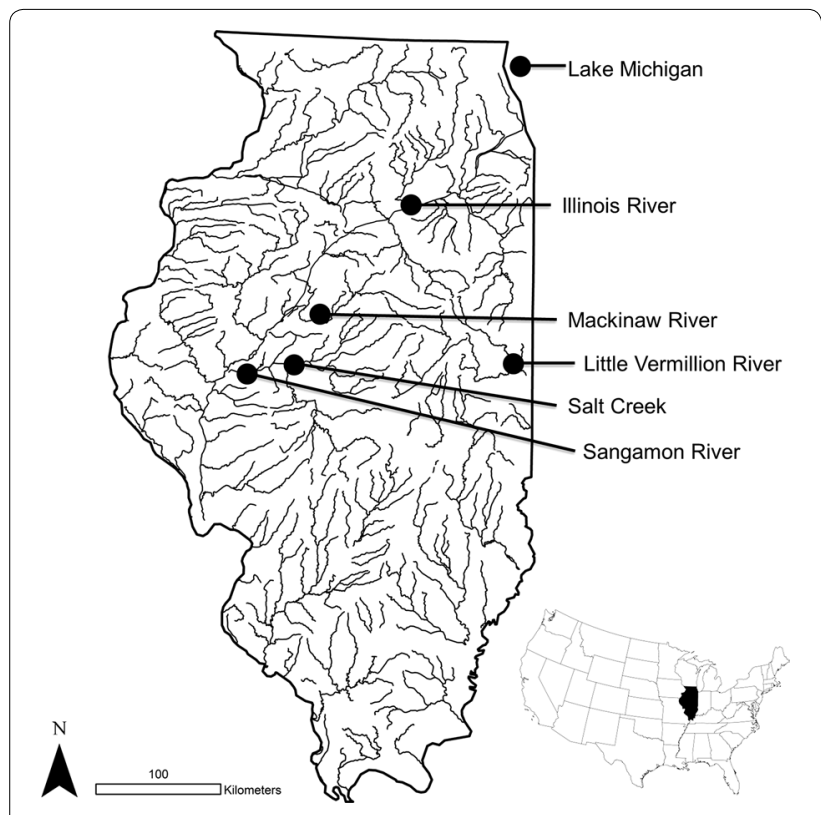

Fig. 1 Map of collection localities and USGS stream gauging stations
tpsDig [35]. To account for bent specimens in collection jars, four additional lateral landmarks, not included in the shape analyses, were added along the midline of each individual to digitally unbend specimens using the 'unbend function' within tpsUtil [36]. Only adult individuals were photographed and digitized. Centroid size was calculated to infer body size of digitized individuals [37]. Sex was determined by gonad inspection. Only collections preserved for a minimum of five years were used to avoid preservation bias in shape that can occur during initial formalin fixation and long term ethanol storage using standard museum preservation protocols [38].

\section{Habitat of rivers and lakes}

To characterize flow habitat of lotic sites, daily discharge data from United States Geological Survey (USGS) stream gauging stations (http://waterdata.usgs.gov/) were used to describe site flow conditions (Table 1). Gauging stations were selected from the same streams (less than $15 \mathrm{~km}$ from site) as biological collections. Daily discharge data were analyzed using two approaches. First, annual mean and variation (coefficient of variation) were calculated from daily discharge data spanning a full calendar year prior to collection to specifically capture the flow conditions leading up to each individual collection effort. Second, overarching site level trends using all available years (including both collection and non-collection years) were analyzed for larger scale emergent patterns with year using the Indicators of Hydrologic Alteration (IHA) [39] flow regime methodology (calculated using IHA software ver. 7.1, The Nature Conservancy). For this broad scale hydrology analysis, all available years were used to provide a hydrology description of the entire site depicting the dominant hydrological trends through time that each lotic fish population had experienced over time. IHA calculates 32 hydrological variables in five categories including magnitude, frequency of occurrence, duration of flow condition, timing, and flashiness [1] and provides a measure of change in these individual variables with time using regression analysis. These IHA variables were identified as ecologically relevant, particularly with regard to feeding, reproduction, maturity, timing of life cycle periods, and stress [39]. In summary, magnitude is a measure of wet volume and can serve as an indication of high versus low flows. Frequency of occurrence is a measure of how episodic extremes in flow magnitude (high or low) occur. Duration of flow condition is a measure of the longevity of different flow events. Timing is a measure of when in a Julian water year extreme conditions occur. The flashiness category is a measure of the rate of change attributed with variation in flow conditions. Departures from the natural flow regime were linked to anthropogenic modifications of rivers, either 


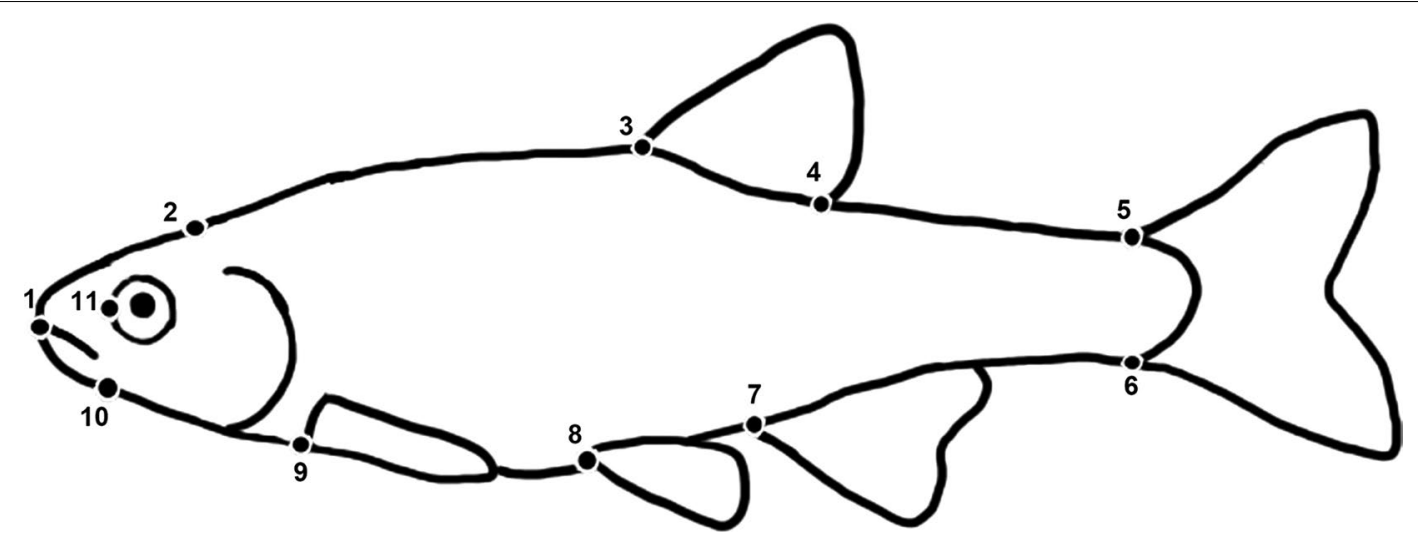

Fig. 2 Location of morphology landmarks. Landmarks correspond to anterior snout (1), superior margin of head (2), anterior dorsal origin (3), posterior dorsal origin (4), superior posterior caudal peduncle (5), inferior posterior caudal peduncle (6), anterior anal fin origin (7), anterior pelvic fin origin (8), superior pectoral fin origin (9), ventral opercular isthmus (10), and anterior medial edge of orbital socket (11)

Table 1 List of USGS gauging stations by drainage basin and include years

\begin{tabular}{|c|c|c|c|}
\hline Site code & $\begin{array}{l}\text { Drainage } \\
\text { basin }\end{array}$ & Site & $\begin{array}{l}\text { Hydrology } \\
\text { years }\end{array}$ \\
\hline USGS 05582000 & Illinois River & Salt Creek at Greenview & 1940-2003 \\
\hline USGS 05583000 & Illinois River & $\begin{array}{l}\text { Sangamon River at } \\
\text { Oakford }\end{array}$ & 1910-2005 \\
\hline USGS 05543500 & Illinois River & Illinois River at Marseilles & 1919-2003 \\
\hline USGS 05568000 & Illinois River & $\begin{array}{l}\text { Mackinaw River at Green } \\
\text { Valley }\end{array}$ & $1921-2000$ \\
\hline USGS 03339000 & Wabash River & $\begin{array}{l}\text { Little Vermillion River at } \\
\text { Danville }\end{array}$ & 1914-2002 \\
\hline
\end{tabular}

directly or indirectly $[1,39]$. Since hydrological information was only available for lotic sites, and no direct habitat information was available for lentic sites, only time was able to be used as an indirect approximation of habitat change [40]. Time also served as a covariate in lotic system analyses. Although not mechanistic in nature, time is indirectly linked to changes in water quality and habitat in the Midwestern United States over the past century [40].

\section{Modeling morphology}

General procrustes analysis (GPA; least squares method) was used to superimpose digitized individuals to a reference or consensus shape by removing effects of scaling, rotation, and translation, allowing comparisons among individuals [36]. Relative Warp Analysis (RWA) was performed in tpsRelw [37] and used to assess total morphological variation among individuals. RWA is essentially a morphometric principal components analysis of relative landmark positions (using variance/covariance matrix) and produces a series of orthogonal axes ranked by the amount of shape variation explained [41]. All shape axes were retained for analyses in this study. Two sets of RWA analyses were performed on individuals, including a family level analysis which incorporated all individuals from all species to test for macro level interspecific effects across species as well as a series of separate RWAs for each species at each site to test for intraspecific variation.

Table 2 List of taxa with collection site, collection year, and number of collections per site

\begin{tabular}{|c|c|c|c|c|}
\hline Species & Collection site & Collection years & $\begin{array}{l}\text { Number of } \\
\text { collections }\end{array}$ & Mean sample ( \pm SE) \\
\hline Striped Shiner Luxilus chrysocephalus & Sangamon River & $1901-2001$ & 9 & $n=15(2.4)$ \\
\hline Redfin Shiner Lythrurus umbratilis & Little Vermillion River & 1899-2002 & 9 & $n=14(2.1)$ \\
\hline \multirow[t]{2}{*}{ Emerald Shiner Notropis atherinoides } & Illinois River & 1897-2003 & 8 & $\mathrm{n}=13(1.2)$ \\
\hline & Lake Michigan & 1900-1999 & 7 & $n=15(3.6)$ \\
\hline \multirow[t]{2}{*}{ Sand Shiner Notropis stramineus } & Sangamon River & $1901-2005$ & 9 & $n=17(3.4)$ \\
\hline & Mackinaw River & $1901-2000$ & 11 & $n=14(2.4)$ \\
\hline \multirow[t]{2}{*}{ Bluntnose Minnow Pimephales notatus } & Salt Creek & $1900-2003$ & 9 & $\mathrm{n}=10(1.0)$ \\
\hline & Lake Michigan & 1900-1998 & 6 & $n=13(4.5)$ \\
\hline
\end{tabular}


Shape axes were treated as dependent variables in multivariate analysis of covariance (MANCOVA) models to test for relative influence of the following factors: species, site, body size, hydrology, sex, year, and all biologically relevant interactions (interpreted through heterogeneous slopes; [42]). Given the exploratory nature of the study, the following terms and interactions were included in the family combined model: species, site, body size, sex, year, daily discharge mean, daily discharge variation, body size * species, sex * species, year * species, daily discharge mean " species, and daily discharge variation * species while the following terms and interactions were included in the species specific models: body size, sex, year, daily discharge mean, daily discharge variation, body size * sex, body size * daily discharge mean, body size * daily discharge variation, daily discharge mean * year, daily discharge variation " year, daily discharge mean " sex, daily discharge variation " sex, and sex " year. Initial models revealing insignificant interaction terms were rerun without interaction terms. An unbalanced MANCOVA design was used to accommodate some limited cases of missing data of certain columns, such as where hydrological records were missing [43]. We felt inclusion of all samples and time periods were relevant as they contained information particular to specific trends (e.g. testing for temporal trends in cases where hydrological information was missing). Prior to a given terms inclusion in the family or species level MANCOVA models, issues with multicollinearity were assessed using variance inflation factor (VIF) statistics with a cutoff of 2.5 [44]. In instances where a variable exceeded this VIF threshold, that variable was dropped from the model and the model was rerun. Wilk's lambda was used to calculate $F$ values and Pillai's partial eta ${ }^{2}$ was used to infer effect size by variance explained. Partial eta ${ }^{2}$ reflects the proportion of variation explained by a given independent variable while parsing out variation from other independent variables. As such, partial eta $^{2}$ values are not necessarily able to be summed to 1.0 but can provide a degree of variation explained, particularly relative to other variables included in the model [45]. In addition to relative warp analyses with MANCOVA models, total morphological disparity was calculated to compare species. Disparity indices can be useful in discerning relative degrees of variability between species or groups and may contribute to our understanding of specific variation over long sampling time periods or provide general evolutionary information to larger order taxonomic groups $[46,47]$. Disparity was calculated from Procrustes coordinates using a randomized residual permutation procedure using 1000 permutations [48]. All models were implemented in the statistical language $R$ (version 2.14.1, R Development Core Team, 2011) using the heplots [45], fmsb [43], geomorph [48], and base stats packages. Thin plate spline deformation grids [49] (produced in tpsRegr [50]) were used to visualize shape variation indicated in MANCOVA models. Alpha was 0.05 for all tests of significance.

\section{Results}

Museum collections of Cyprinidae were from long term $(100+$ year) collections at five lotic sites (Sangamon River, Salt Creek, Little Vermillion River, Mackinaw River, and Illinois River), all with adjacent USGS daily discharge monitoring sites, and one lentic site (Lake Michigan). Specimen collection dates ranged from 1899 to 2006 and spanned 98 to 106 collection years (mean number of collection events per site $=8.5$ ) across the sites (Table 2; Appendix). Number of individuals per collection event included in the analyses ranged from 9 to 34 (mean number of individuals $=13.9$ ). All sites included the available range of body sizes of sexually mature individuals of both males and females. United States Geological Survey (USGS) hydrological archives of daily discharge ranged from 63 to 96 consecutive years at the five lotic sites, with the earliest data collected in 1910 (Table 1). Indicators of Hydrologic Alteration analyses revealed significant alterations for all sites across the five primary IHA categories, including frequency and duration of pulses, magnitude and duration of annual extremes, magnitude of monthly conditions, rate and frequency of water condition changes, and timing of annual extreme conditions (Appendix). Mean number of hydrological alterations (of 32 possible) at sites was 11.4 (range of 1-23 alteration types) with varying degrees of magnitude, indicating that sites were variable in numbers of alterations and the extent these alterations modified the flow regime (Appendix). Overall, Cyprinidae morphology was related to a combination of variables and interaction terms, including body size, sex, hydrology (lotic sites), and time but was not uniformly consistent across species (Tables 3, 4).

\section{Cyprinidae}

The combined analysis at the family level included 908 individuals from 68 lots representing both lotic and lentic sites spanning 1897-2003. Total morphological variation was captured along 18 relative warp axes which explained $100 \%$ of shape variation. However, shape was primarily driven by the first six axes which accounted for $80 \%$ of this variation. The primary morphological gradient extracted from the family level MANCOVA model (aside from the species grouping variable) was body size, which explained $45 \%$ of the total morphological variation. In addition to body size, sex (11\%) and year $(8 \%)$ were also recovered as important contributors to morphological variation. In lotic populations, both discharge 
Table 3 Results from family level MANCOVA model assessing relationships between morphological variables and body size, hydrology, sex, year, and interactions for five species

\begin{tabular}{lllrll}
\hline Family & Effect & $\begin{array}{l}\text { Variance } \\
\text { explained }\end{array}$ & $\boldsymbol{F}$ & d.f. & $\boldsymbol{P}$ \\
\hline Cyprinidae & Species & 0.70 & 2.8 & 72,2004 & $<0.001$ \\
& Body size & 0.45 & 22.7 & 18,498 & $<0.001$ \\
& Sex & 0.11 & 3.6 & 18,498 & $<0.001$ \\
& Year & 0.08 & 2.4 & 18,498 & $<0.001$ \\
& Discharge mean & 0.11 & 3.2 & 18,498 & $<0.001$ \\
& Discharge CV & 0.08 & 2.3 & 18,498 & $<0.001$ \\
& Body size ${ }^{*}$ species & 0.10 & 2.8 & 72,2004 & $<0.001$ \\
& Sex* ${ }^{*}$ species & 0.06 & 1.7 & 72,2004 & $<0.001$ \\
& Year * species & 0.11 & 3.4 & 72,2004 & $<0.001$ \\
& Discharge & 0.08 & 2.5 & 72,2004 & $<0.001$ \\
mean * species & & & & \\
Discharge & 0.09 & 2.6 & 72,2004 & $<0.001$ \\
CV* species & & & & \\
\hline
\end{tabular}

See Table 4 for taxon specific analyses and Figs. 3, 4, 5, 6, 7 for visualizations of shape changes in individual species

mean (11\%) and variation (8\%) were recovered across all taxa. Testing for differences in trajectories of these relationships between species through the species interaction term uncovered significant variation in all cases indicating that there are species level differences in body shape responses to size, sex, year, and hydrology (Table 3). These differences in overall trajectory or slope between species renders an overall visualization less useful than discerning species specific trends as presented in subsequent results with species level visualizations. However, relative to overall morphological variation, disparity analysis indicated significantly different levels of variation across species $(\mathrm{P}<0.05)$ and that the highest amount of morphological variation was found in Striped Shiner followed by Redfin Shiner, Emerald Shiner, Bluntnose Minnow, and Sand Shiner, respectively. Interesting, both species with lake populations, Emerald Shiner and Bluntnose Minnow, exhibited appreciably more variation in the lentic populations compared with their lotic counterparts while the only species with multiple lotic samples (Sand Shiner) were not significantly different from one another.

\section{Striped Shiner}

Striped Shiner collections were from a single lotic site, the Sangamon River, and included 131 individuals from nine lots spanning 1901-2001. Total morphological variation was captured along 18 relative warp axes which explained $100 \%$ of shape variation. This variation was primarily driven by the first 8 relative warp axes which accounted for $87 \%$ of the shape variation. The primary morphological gradient extracted from the Sangamon River MANCOVA model was body size, which explained $63 \%$ of the total morphological variation. Smaller individuals tended to have narrower body, caudal peduncle areas, and fin bases compared to larger individuals. Secondarily, year (49\%) was identified as an important predictor of morphology as individuals from more recent collections tended to exhibit more fusiform morphologies than the deeper bodied individuals from past collections. Hydrological analyses of the Sangamon River site provide a potential causal mechanism that undergirds this year variable. IHA analyses showed significant alterations to 9 (of 32) different types of hydrological variables between 1910 and 2005 (Appendix). Regression slopes for IHA variables with time indicated that the largest hydrologic alteration types occurred in magnitude and duration of annual extremes. Although it was not possible to explicitly incorporate IHA variables into the morphological model, a more direct test of hydrology, variation in annual discharge $(29 \%)$ and mean annual discharge (24\%), also supported a relationship between shape and hydrological variation. Striped Shiner morphologies with downturned heads, shorter and more robust caudal peduncle areas, and generally deeper bodies coincided with higher annual discharge and higher variation in annual discharge. A significant interaction between both year and annual discharge mean, as well as variation in discharge, indicated that something outside of these hydrological parameters is also likely influencing morphological variation independent of time. This variation could be attributed to some other hydrological attribute, such as one measured by the IHA, or reflect an unmeasured habitat variable that has also changed with time. Additionally, interactions recovered between body size and hydrology metrics (daily mean and variation in daily mean) indicated that while there was an overall effect of hydrology on morphology, this relationship was not consistent across all sizes of individuals. Lastly, interactions between sex and year indicated that males and females responded to the time variable differently, despite the lack of overall significance between parent terms. No interaction between sex and hydrology was recovered. See Table 4 and Fig. 3 for model configuration and deformation grids depicting shape change.

\section{Redfin Shiner}

Redfin Shiner collections were from a single lotic site, the Little Vermillion River, and included 104 individuals from nine lots spanning 1899-2002. Total morphological variation was captured along 18 relative warp axes which explained $100 \%$ of shape variation. This variation was primarily driven by the first seven relative 
Table 4 Results from MANCOVA models assessing relationships between morphological variables and body size, hydrology, sex, year, and interactions for five species

\begin{tabular}{|c|c|c|c|c|c|c|}
\hline Species & Site & Effect & $\begin{array}{l}\text { Variance } \\
\text { explained }\end{array}$ & $F$ & d.f. & $P$ \\
\hline Striped Shiner & Sangamon River & Body size & 0.63 & 24.1 & 8,113 & $<0.001$ \\
\hline \multirow[t]{9}{*}{ Luxilus chrysocephalus } & \multirow[t]{9}{*}{$(1901-2001)$} & Discharge mean & 0.24 & 4.6 & 8,113 & $<0.001$ \\
\hline & & Discharge CV & 0.29 & 5.9 & 8,113 & $<0.001$ \\
\hline & & Sex & 0.11 & 1.6 & 8,113 & 0.14 \\
\hline & & Year & 0.49 & 13.7 & 8,113 & $<0.001$ \\
\hline & & Body size * discharge mean & 0.16 & 2.7 & 8,113 & 0.01 \\
\hline & & Body size * discharge CV & 0.15 & 2.4 & 8,113 & 0.02 \\
\hline & & Discharge mean * year & 0.22 & 3.9 & 8,113 & $<0.001$ \\
\hline & & Discharge CV * year & 0.35 & 7.7 & 8,113 & $<0.001$ \\
\hline & & Sex* year & 0.27 & 5.4 & 8,113 & $<0.001$ \\
\hline Redfin Shiner & Little Vermillion River & Body size & 0.18 & 2.3 & 7,73 & 0.04 \\
\hline \multirow[t]{6}{*}{ Lythrurus umbratilis } & \multirow[t]{6}{*}{$(1899-2002)$} & Discharge mean & 0.14 & 1.7 & 7,73 & 0.11 \\
\hline & & Discharge CV & 0.08 & 0.85 & 7,73 & 0.55 \\
\hline & & Sex & 0.28 & 3.9 & 7,73 & $<0.001$ \\
\hline & & Year & 0.21 & 2.8 & 7,73 & 0.01 \\
\hline & & Body size * discharge mean & 0.23 & 3.1 & 7,73 & $<0.001$ \\
\hline & & Discharge mean * year & 0.26 & 3.6 & 7,73 & $<0.001$ \\
\hline Emerald Shiner & Illinois River & Body size & 0.35 & 4.3 & 8,71 & $<0.001$ \\
\hline \multirow[t]{9}{*}{ Notropis atherinoides } & \multirow[t]{4}{*}{$(1897-2003)$} & Discharge mean & 0.23 & 2.7 & 8,71 & 0.02 \\
\hline & & Discharge CV & 0.69 & 19.5 & 8,71 & $<0.001$ \\
\hline & & Sex & 0.32 & 4.2 & 8,71 & $<0.001$ \\
\hline & & Year & $*$ & $*$ & * & * \\
\hline & Lake Michigan & Body size & 0.51 & 14.8 & 6,85 & $<0.001$ \\
\hline & \multirow[t]{4}{*}{$(1900-1999)$} & Sex & 0.27 & 5.3 & 6,85 & $<0.001$ \\
\hline & & Year & 0.41 & 9.2 & 6,85 & $<0.001$ \\
\hline & & Body size ${ }^{*}$ sex & 0.19 & 3.2 & 6,85 & $<0.01$ \\
\hline & & Sex* year & 0.17 & 2.9 & 6,85 & $<0.01$ \\
\hline Sand Shiner & Sangamon River & Body size & 0.39 & 8.6 & 8,108 & $<0.001$ \\
\hline \multirow[t]{9}{*}{ Notropis stramineus } & \multirow[t]{4}{*}{$(1901-2005)$} & Discharge mean & 0.41 & 9.3 & 8,108 & $<0.001$ \\
\hline & & Discharge CV & 0.42 & 9.7 & 8,108 & $<0.001$ \\
\hline & & Sex & 0.24 & 4.2 & 8,108 & $<0.001$ \\
\hline & & Year & 0.11 & 1.6 & 8,108 & 0.14 \\
\hline & Mackinaw River & Body size & 0.3 & 3.5 & 8,64 & $<0.001$ \\
\hline & \multirow[t]{4}{*}{$(1901-2000)$} & Discharge mean & 0.19 & 1.9 & 8,64 & 0.05 \\
\hline & & Discharge CV & 0.08 & 0.69 & 8,64 & 0.71 \\
\hline & & Sex & 0.11 & 0.95 & 8,64 & 0.48 \\
\hline & & Year & $*$ & $*$ & * & $*$ \\
\hline Bluntnose Minnow & Salt Creek & Body size & 0.61 & 11.1 & 7,49 & $<0.001$ \\
\hline \multirow[t]{8}{*}{ Pimephales notatus } & \multirow[t]{5}{*}{ (1900-2003) } & Discharge mean & 0.24 & 2.2 & 7,49 & 0.05 \\
\hline & & Discharge CV & 0.06 & 0.4 & 7,49 & 0.87 \\
\hline & & Sex & 0.42 & 5.1 & 7,49 & $<0.001$ \\
\hline & & Year & 0.16 & 1.3 & 7,49 & 0.26 \\
\hline & & Body size * sex & 0.38 & 4.4 & 7,49 & $<0.001$ \\
\hline & Lake Michigan & Body size & 0.64 & 17.5 & 7,68 & $<0.001$ \\
\hline & \multirow[t]{2}{*}{ (1900-1998) } & Sex & 0.31 & 4.4 & 7,68 & $<0.001$ \\
\hline & & Year & 0.18 & 2.1 & 7,68 & 0.05 \\
\hline
\end{tabular}




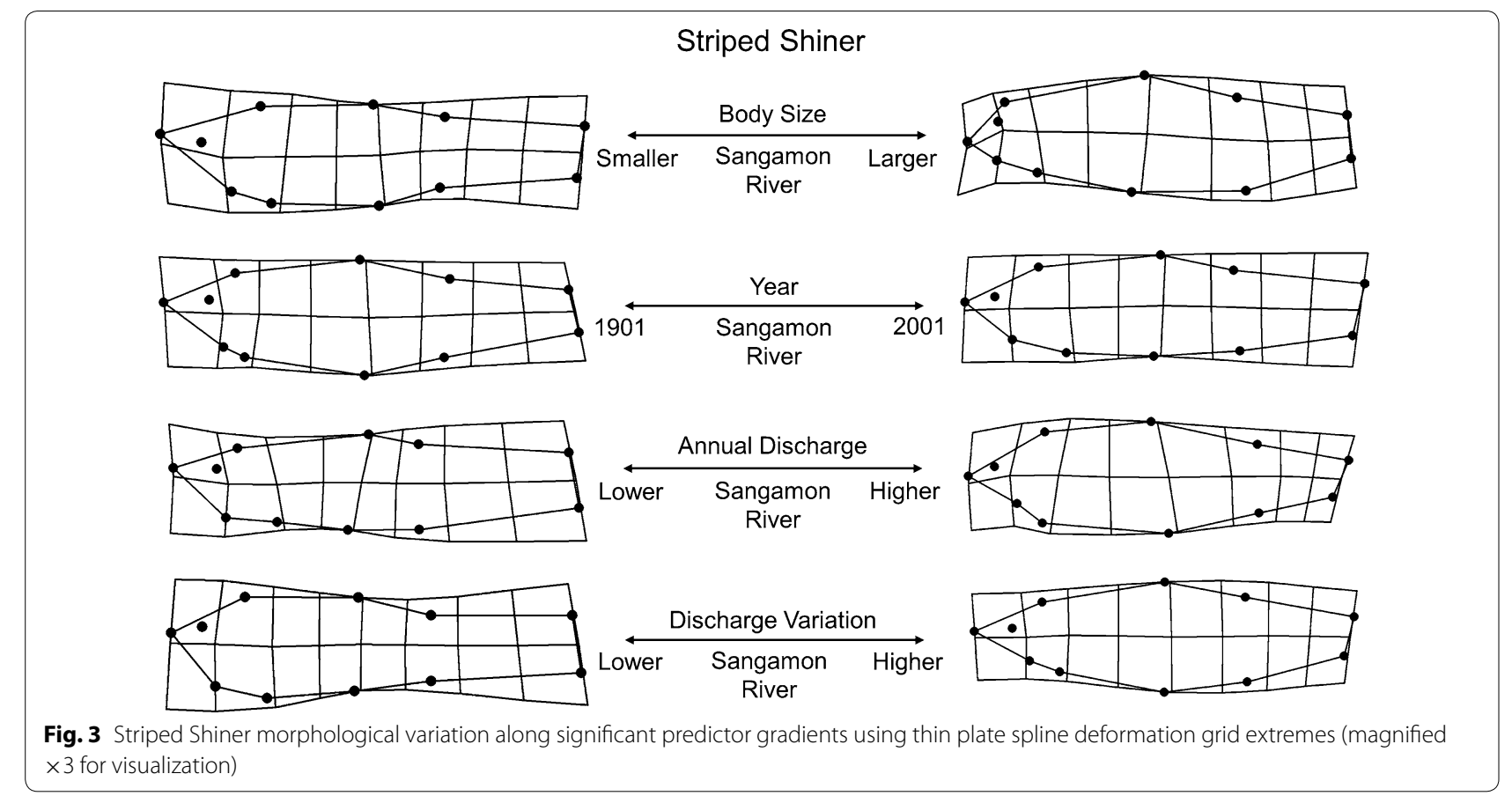

warp axes which accounted for $81 \%$ of the shape variation. The primary morphological gradient extracted from the MANCOVA model was sex, which explained $28 \%$ of the total morphological variation. Females were found to exhibit deeper abdomens than males, however, this was not found to relate with any interactions with body size, hydrology, or year indicating consistent differences among body sizes, hydrology variables, sex differences, and year. Secondarily, year (28\%) and body size (18 \%) were both significant main factors in morphological variation. More recent collections tended to exhibit comparatively smaller head shapes, a more arched dorsal surface, increasingly posterior pelvic and dorsal fin placements, and deeper caudal peduncles than older collections. Related to time, IHA analyses of the Little Vermillion River site showed significant hydrologic alterations in 19 (of 32) different types of IHA variables between 1915 and 2002 (Appendix). Regression slopes for IHA variables with time indicated that the largest alterations occurred in the magnitude and duration of annual extremes. Relative to body size, larger fish were found to be deeper bodied with shorter head areas compared with smaller bodied individuals. Although neither mean daily discharge or variation in daily discharge were significant, the model did recover interaction between mean daily discharge and time as well as body size, related to $26 \%$ and $23 \%$ of the variation, respectively. See Table 4 and Fig. 4 for model configuration and deformation grids depicting shape change.

\section{Emerald Shiner}

Emerald Shiner collections were from a single lotic site, the Illinois River, and one lentic site, Lake Michigan, and included 198 individuals from 15 lots spanning 18972003. Total morphological variation for Illinois River and Lake Michigan individuals was captured along 18 relative warp axes which encompassed $100 \%$ of the variation in each analysis, but was primarily driven by 8 and 6 relative warp axes that accounted for 86 and $84 \%$ of shape variation Illinois River and Lake Michigan populations, respectively.

The primary morphological gradients extracted from the Illinois River model were hydrological, including variation in annual discharge (69 \%) and mean annual discharge (23\%). More fusiform individuals with downward turned and extended caudal peduncle areas tended to occur during periods of lower mean annual discharge and higher variation in this discharge. In addition to hydrology, shape of Illinois River individuals also correlated with variation in body size (35\%) and sex (32\%). Larger individuals tended to exhibit deeper bodies, more robust caudal peduncles, and narrower heads compared with smaller individuals. In addition, females also tended to exhibit deeper bodies with more robust caudal peduncles compared with males. Issues with multicollinearity (VIF > 2) necessitated the exclusion of year from the Illinois River model. No interaction terms were recovered in this model, indicating a lack of sex-specific allometry or hydrological covariates. Although time was excluded 


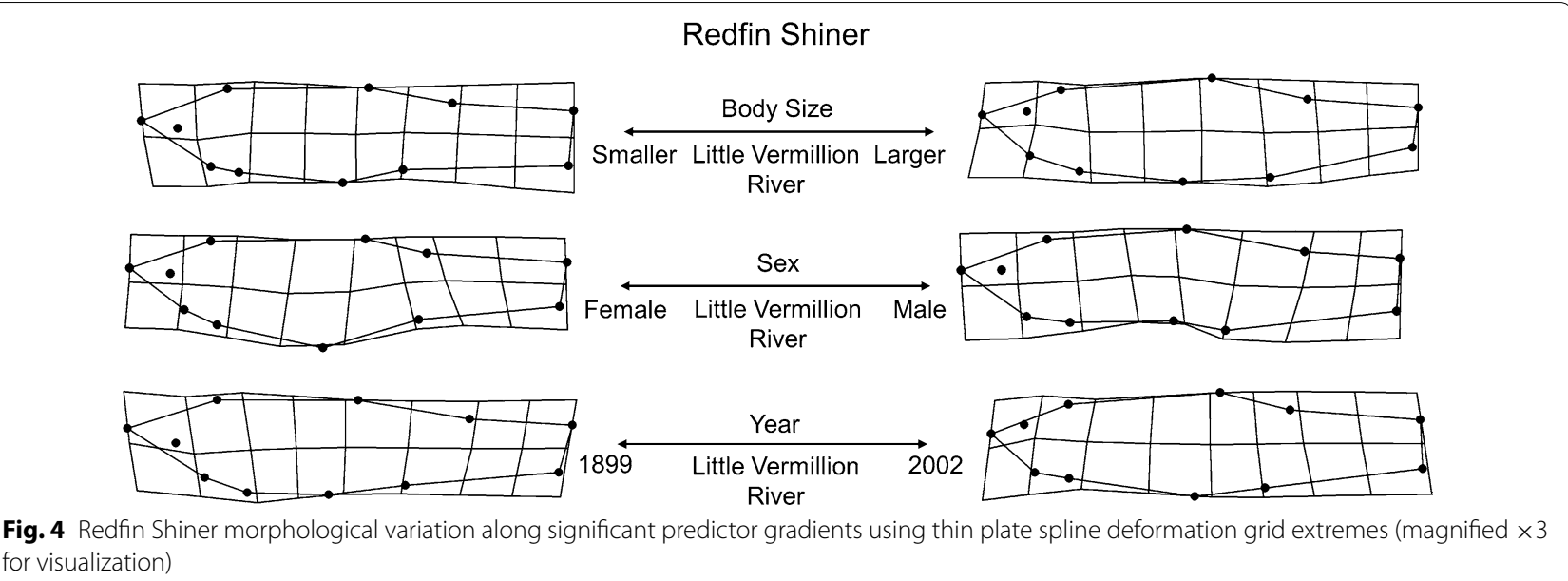

from the model due to issues with multicollinearity, hydrological analyses of the Illinois River site revealed significant hydrologic alterations to 23 (of 32) IHA variables between 1920 and 2003 (Appendix). Regression slopes for IHA variables with time indicated that the largest alterations occurred with magnitude and duration of annual extremes.

The primary morphological gradients extracted from the Lake Michigan model were body size (51\%), year (41\%), and sex (27\%). Similar to collections from the Illinois River, larger individuals and females tended to be deeper bodied with more upturned heads and comparatively robust caudal peduncle areas. Interestingly, a significant interaction between body size and sex (19\%), not recovered in the Illinois River model, was recovered in the Lake Michigan model, indicating a degree of sexspecific allometry present in Lake Michigan collections. Lastly, year was explained by more recent collections of increasingly fusiform shaped individuals with upturned and narrower head and caudal shapes compared with older collections. This relationship between body shape and time was compounded by an interaction with sex, indicating a difference in degree of response to time between males and females. See Table 4 and Fig. 5 for model configuration and deformation grids depicting shape change.

\section{Sand Shiner}

Sand Shiner collections were from two lotic sites, the Sangamon River and Mackinaw River, and included 306 individuals from 20 lots spanning 1901-2005. Total morphological variation explained for Sangamon River and Mackinaw River individuals was captured along 18 relative warp axes that explained $100 \%$ of the total variation in each population. This variation was primarily driven by eight axes in each case which accounted for
84 and $83 \%$ of the total morphological variation among Sangamon and Mackinaw River individuals, respectively. Among the primary morphological gradients extracted from both the Sangamon River and Mackinaw River MANCOVA models was body size, which explained 39 and $30 \%$ of the total morphological variation, respectively. Both sites exhibited similar allometric shape trends related to increased dorsal fin base, anterior placement of pectoral fin, as well as deepening of the body and head concurrent with increased body size. Sangamon River populations were further described by high levels of sex-specific ( $24 \%$ variance explained) differences, primarily related to more distended abdomens in females compared with males. Lack of an interaction between body size and sex retained in the final model indicated homogeneity of slopes between males and females in the size range included in this analysis, despite differences in overall body shape. This high degree of sex difference in body shape was different from Mackinaw River populations where sex was related to only $11 \%$ of variation and was not recovered as statistically significant in the final model. Hydrological variables provided explanation for Sangamon River and Mackinaw River morphologies as higher levels of mean discharge for both the Sangamon (41\%) and Mackinaw (19\%) Rivers were positively related to deeper bodied and more robust individuals. Higher levels of variation in mean daily discharge tended to relate ( $42 \%)$ to increasingly fusiform shapes with higher arched dorsal surfaces in Sangamon River populations only. Lastly, time was not recovered as a significant predictor of morphology in either model as issues with multicollinearity (VIF $>2$ ) warranted exclusion of year from the Mackinaw River model and nonsignificant model terms precluded interpretation in the Sangamon River model. However, hydrological analyses of the Mackinaw River site elicited significant hydrologic 


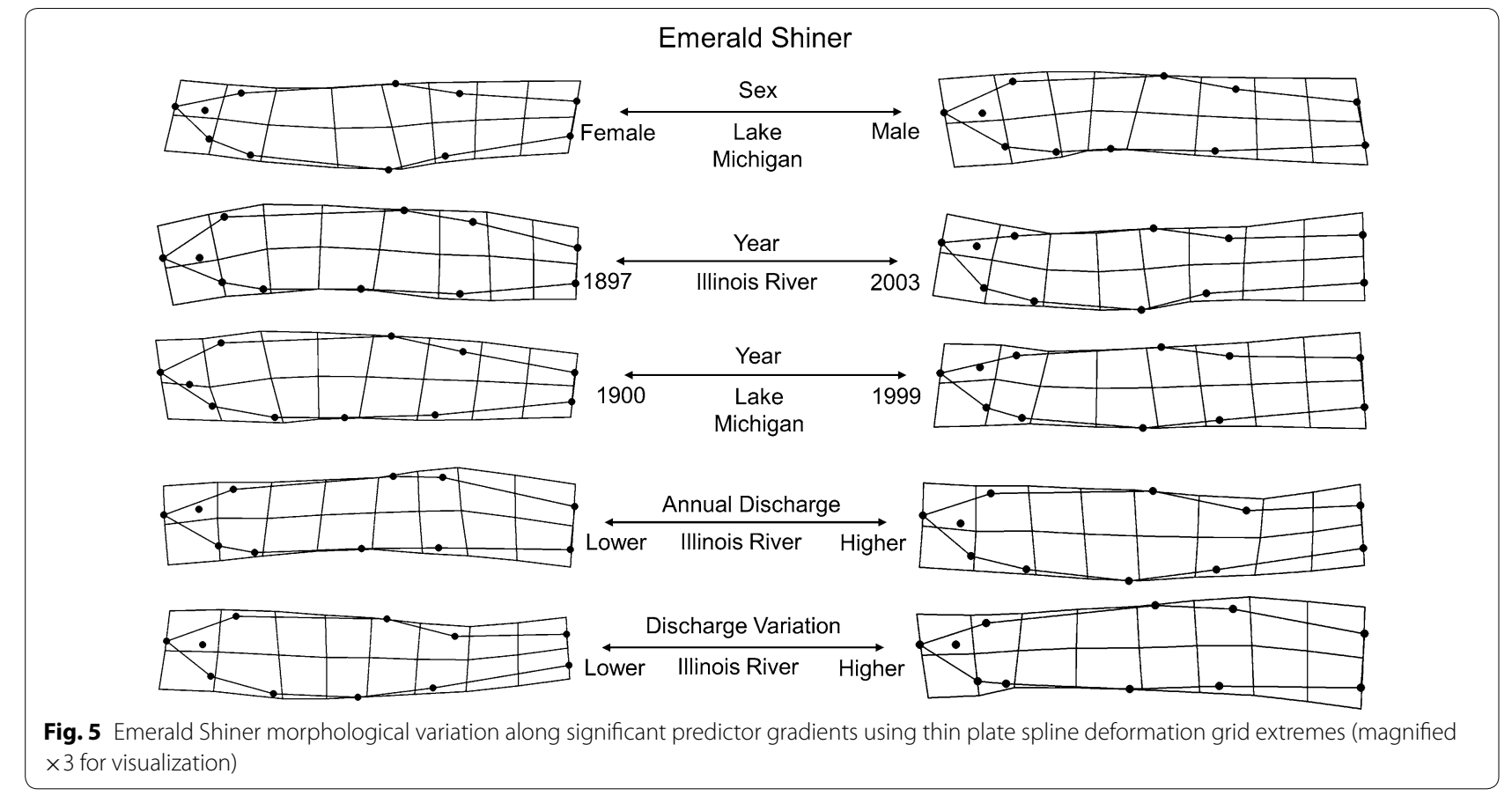

alterations to 1 (32) type of IHA variable between 1922 and 2000 (Appendix). Regression slopes for IHA variables with time indicated a reduction in high pulse numbers in more recent Mackinaw River years. Similarly, hydrological analyses of the Sangamon River showed significant alterations to 9 (of 32) of the measured IHA type variables between 1910 and 2005 (Appendix). Regression slopes for IHA variables with time indicated that the largest alterations in the Sangamon River occurred in magnitude and duration of annual extremes. No relationships were recovered between sex and hydrology, sex and body size, or sex and time at either site, indicating similar slopes. See Table 4 and Fig. 6 for model configuration and deformation grids depicting shape change.

\section{Bluntnose Minnow}

Bluntnose Minnow collections were from one lotic site, Salt Creek, and one lentic site, Lake Michigan, and included 169 individuals from 15 lots spanning 19002003. Total morphological variation explained for Salt Creek and Lake Michigan individuals was captured along 18 relative warp axes that explained $100 \%$ of the total variation in each population. This variation was primarily driven by seven axes in each case which accounted for 83 and $87 \%$ of the total morphological variation among Salt Creek and Lake Michigan individuals, respectively. The primary morphological gradient extracted from both Salt Creek and Lake Michigan MANCOVA models was body size, which explained 61 and $64 \%$ of the total morphological variation, respectively. Both sites exhibited similar shape trends with increasing body size, including an increasingly downward facing snout, deeper body, and more robust caudal region. In addition to body size, both sites exhibited significant variation attributable to sex ( 42 and $31 \%$, respectively). Females from both sites differed from males by deeper abdomens and less overall arching of the dorsal surface. Collections from Salt Creek also demonstrated strong signal (38 \%) from the body size and sex interaction term, indicating a higher degree of sex-specific allometric slope differences compared with Lake Michigan individuals. Relative to time, collections from Lake Michigan (18\%) indicated that individuals from collections in recent years had longer and narrower caudal regions, more terminal snouts (compared with superior snouts in past years), more fusiform overall body shapes, and a reduction in dorsal fin base length than past years. Time did not have a significant effect on morphology of individuals from Salt Creek. However, hydrological analyses of Salt Creek site during this time identified significant alterations in 6 (of 32) types of IHA variables between 1942 and 2005 (Appendix). Regression slopes for IHA variables with time indicated that the largest hydrologic alterations occurred in magnitude and duration of annual extreme flow events. Salt Creek hydrology variables supported a relationship between morphology and daily discharge mean (24\%) as higher values coincided with increasingly fusiform individuals compared with more robust individuals typical of 

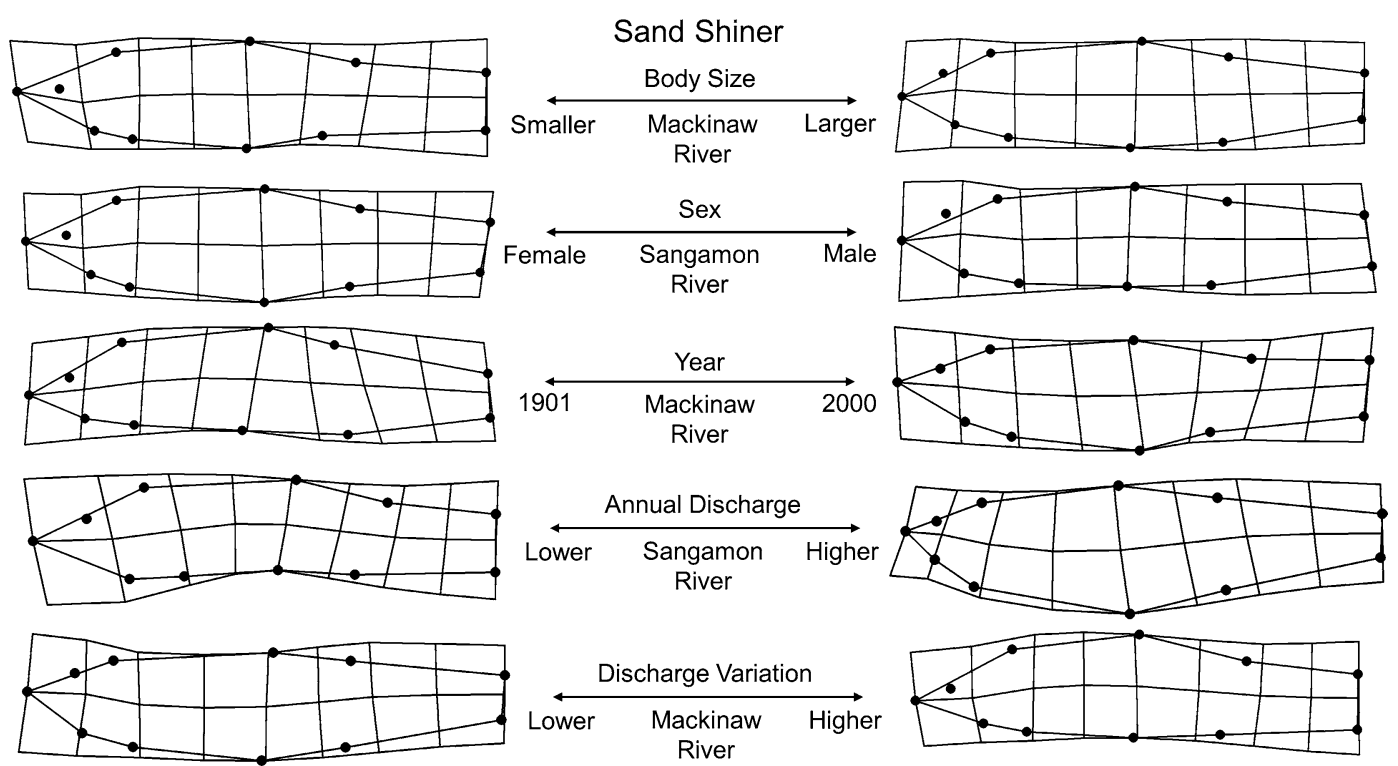

Fig. 6 Sand Shiner morphological variation along significant predictor gradients using thin plate spline deformation grid extremes (magnified $\times 3$ for visualization)

lower daily discharge mean values. Salt Creek Bluntnose Minnow morphological variation over these years did not demonstrate a significant effect from time. Similarly, no interaction terms were recovered between sex and hydrology, body size and hydrology, or sex and year. See Table 4 and Fig. 7 for model configuration and deformation grids depicting shape change.

\section{Discussion}

Morphological models identified significant shape relationships with body size, sex, hydrology, time, and a series of interactions in this exploratory study of fish shape variation over the past 100 years. Several trends emerged that indicated similarities and differences in the relative contributions of each variable. However, no universal pattern or formula described Cyprinidae shape over the past century consistently across species. Overall, body size trends tended to be similar among taxa as larger individuals tended to be deeper bodied, exhibit narrower head shapes, show arching of the dorsal surface, and have compressed caudal peduncle regions relative to smaller individuals. In addition, sex-specific differences among species were present in the species measured and were generally driven by females which exhibited deeper or distended abdominal regions compared with males. In lotic sites only, responses to hydrological variables such as mean annual discharge or variation in discharge were present in most species but directionality of morphological responses was not consistent among species as some tended to be more fusiform with higher discharge or variation in discharge, while others demonstrated increased robustness. Lastly, time was recovered in almost every model as an important contributor to morphological variation, however directionality also varied between species. This variability associated with time was not surprising, as the time variable is without a true mechanism measured over this century time span, and may reflect habitat variation at local and/or regional scales. Interactions among variables were far less consistent but did provide important controls for detecting differences in slopes between independent variables [42] At the family level, the species level interaction term uncovered differences in slopes by species while at the intraspecific level interaction terms uncovered variation in allometry, sexual dimorphism, responses to flow, and time.

\section{Body size and allometry}

Morphological variation along body size gradients was expected as resource utilization in fishes typically changes during development into adulthood consistent with ontogenic relationships to niche $[12,13]$. These aspects of body size and morphological relationships are frequently linked to prey selection, competition, microhabitat choice, and predator-prey dynamics [8, 51]. Results of this study supported a general change in morphology across species consistent with body size; however, directly linking this variation to local environments was not possible. An exception to this was information gleaned from the interaction terms with body size, as 


\section{Bluntnose Minnow}
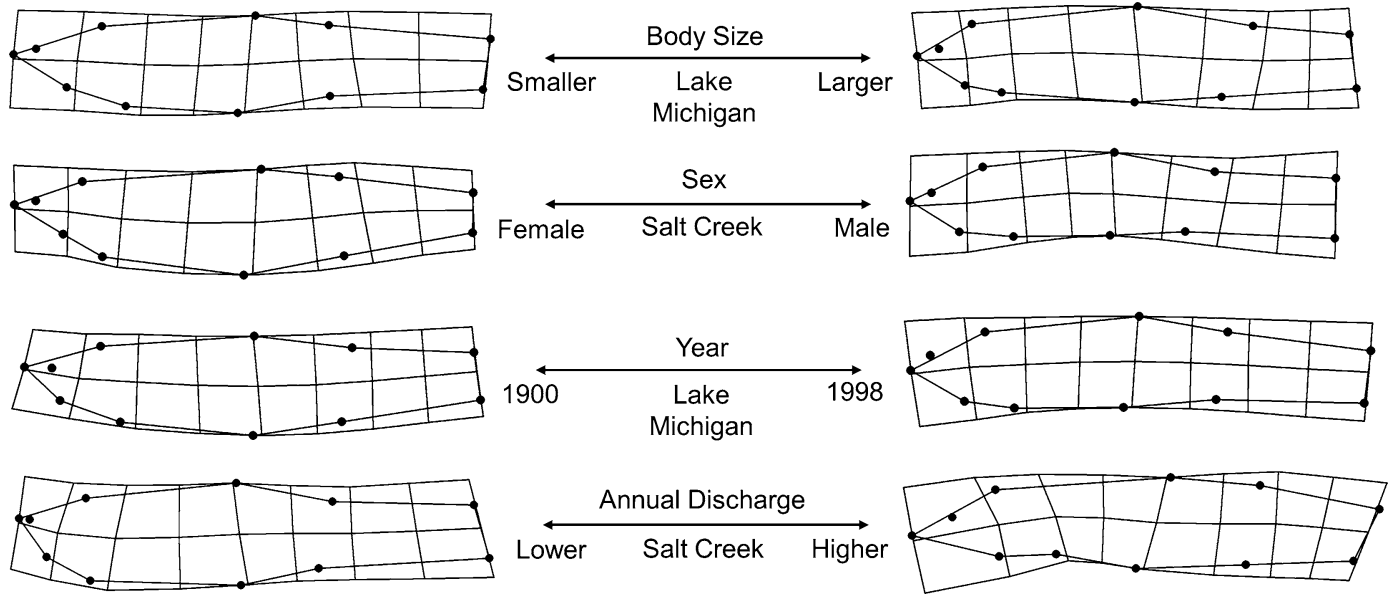

Fig. 7 Bluntnose Minnow morphological variation along significant predictor gradients using thin plate spline deformation grid extremes (magnified $\times 3$ for visualization)

several species showed relationships between size and sex as well as size and hydrology, suggesting that the allometric scaling relationship is contingent on a variety of factors that may affect survival. Interestingly, these interactions were not consistent across taxa or sites. Moreover, the effect of body size was not consistent in strength of relationships across taxa. Consequently, this might suggest different levels of selection for the body shape and body size relationship across Cyprinidae.

\section{Sexual dimorphism}

Morphological variation by sex was predicted as an effect of functional selection $[52,53]$ related to fecundity constraints due to ovary size relative to testes [54-56]. However, sexual shape dimorphism is not ubiquitous in Cyprinidae taxa [57]. Our results support this mixed result as sex-specific shape differences were not consistent across taxa or sites as evidenced by varying effects of sex between species and sites, as well as results failing to meet initial expectations of heterogeneity of body size slopes with sex. We suggest that this could be a result of either a real signal (or lack thereof) of sex-specific shape differences that are taxon-specific within Cyprinidae, or an artifact of the body size ranges available and used in this study. Interestingly, shape variation between males and females also seemed to fluctuate among sites, particularly for comparison of the lake to rivers, where lotic samples reflected a higher degree of sexual shape dimorphism in both species tested (Bluntnose Minnow and Emerald Shiner with lotic and lentic sites) than either of their lentic system counterparts. In addition, there were no interactions between sex and hydrology, where one might expect male morphologies to show a stronger response to flow than females given reproductive constraints on body shape [57]. Our results did not support our a priori hypotheses $[52,53]$ regarding constraints on female morphology with selection for increased fecundity, as both male and female fishes responded similarly to varying hydrology. It seems plausible that a factor beyond often cited fecundity constraints may be responsible for the varying signal. For example, subtle differences in shape between sexes may translate to variation in niche space (e.g. diet, resource utilization, etc.) and potential release of competition. More research in the field and lab is needed into the variability within and between species and between sexes that explore potential hypotheses relating to niche, hydrology, fecundity, and morphological variability.

\section{Hydrological influence}

Changes in morphology with hydrology indicate the presence of environmental influences on morphology. And while hydrology is by no means the only potential environmental corollary of morphology, it represents a strong potential environmental mechanism to explain changes over time. This variation in morphology could be rooted in selective variation or occur as a result of phenotypic plasticity, however, these two potential mechanisms are not necessarily mutually exclusive. It is unlikely that field data without the addition of any population genetic component could be used to distinguish between the two. However, phenotypic plasticity likely contributes to the trends elicited in this study as several of the fishes exhibited exceptionally strong relationships with both mean annual discharge and with variation of discharge. Unfortunately, the relative contribution of plasticity in response 
to local environmental conditions or population genetic divergence to morphological variation is unknown for most taxa [11]. Determining whether plasticity, directional selection towards a specific morphology, or some combination thereof results in morphological covariation with the environment can further distinguish potential adaptations. However, this requires genetic information that is difficult to obtain following formalin fixation and long term ethanol museum storage [58].

This study complements contemporary hydrology and morphology studies, which typically only address hypotheses involving current environmental measurements and current fish samples by adding a long term component. The predominant trend among short term intraspecific morphology-hydrology studies is that individuals with deeper-bodied morphologies tend to occur in lower flow velocity reaches of lotic or in lentic ecosystems, whereas individuals with more fusiform morphologies tend to occur in high flow conditions [14-16]. We found that not all Cyprinidae taxa exhibited a significant signal with hydrology variation. Moreover, not all species demonstrated the same response to high levels of mean annual flow or variation of annual flows. High flow velocities are expected to select for morphology that is a fusiform shape, and the opposite with low flows because of the resistance-performance relationship resulting from hydrological drag in high vs low velocity waters that can accompany flow volumes [59]. One caveat that may explain the differences identified here is that high discharge does not necessarily translate to velocity, and in fact may have an opposite effect, as higher volumes can overflow into floodplains, resulting in reaches with relatively low velocity. Furthermore, although not a direct objective of this study, visualization of consensus shapes between lentic and lotic sites suggested that individuals from lentic sites tended to be deeper-bodied than lotic individuals. However, future studies should directly quantify this with additional Cyprinidae species to test whether the pattern emerges across all species or is taxon specific since this study was based more on site level replicates through time and less on spatial replicates [26].

\section{Long term habitat change}

In this study, while hydrology served as a direct mechanism of morphological change, time was used an indirect metric of change and can function as a notice of some unmeasured abiotic or biotic alteration. In several instances, time was excluded because it was essentially synonymous with variation in included hydrology variables. In these instances, hydrology is likely the primary determinant of environmentally driven shape change. However, in other instances where time was not related to mean annual discharge or discharge variation, it provides a unique perspective in the MANCOVA models independent of the hydrological factors directly assessed. However, hydrological variation can be assessed using a variety of metrics or approaches and the IHA analyses elicited several other hydrological parameters that also fluctuated with time. Other variables, in addition to hydrological variation, that would improve understanding of Cyprinidae morphology include disentangling the relative contributions from microhabitat, individual movement and dispersal potential, community structure, and phylogenetic history [15, 60-66]. Incorporation of these additional details into Cyprinidae morphology studies may provide a better understanding of morphological evolution-and by extension improve understanding of large scale ecosystem, community, and conservation issues.

\section{Systematic, ecosystem, and community implications}

Temporal variation in morphology can result from immigration, selection, or other causes [67]. Therefore the presence of temporal morphological variation can prevent or disrupt long term ecological conclusions based off of a single sample from a single site. This study utilized multiple samples from numerous sites for several species and could provide a useful template or model for understanding long term changes in the environment and resulting morphologies of fishes. The variation in morphology documented herein can contribute to our understanding of variation in large scale ecosystem processes in light of ecomorphology [7, 68-70]. Ecosystem attributes such as primary production, nutrient cycling, and stability are linked to functional richness and diversity [71]. Therefore, we may better understand how these changes can influence large scale processes by providing clear mechanisms to what drives form. For example, in a recent Cyprinidae study, Wanink and Witte [72] demonstrated morphological differentiation that coincided with a pelagic to benthic niche shift as a result of an ecological disturbance. Similarly, Eklöv and Svanbäck [9] identified a predator- and habitat-induced shift in morphology that coincided with resource specialization. However, despite few studies that documented linkages between morphological variation and ecosystem attributes, more direct comparisons or experiments are necessary. This study describes morphological variation that coincides with several metrics that relate to organismal function. As morphology changed with time as documented in the model one can postulate potential shifts in the ecosystem pertaining to energy, habitat, or other members of the community. However, studies that directly address the hypothesis of ecosystem covariation with intraspecific morphological variation may be confounded by multiple interspecific population responses contributing to an 
ecosystem process. In addition, hydrological alterations directly influence ecosystem processes and are present in the majority of lotic and lentic systems worldwide [25]. Thus, the ability to manipulate a single population within an ecosystem and measure an indirect effect of morphological change on ecosystem properties may be possible only in laboratories or mesocosm experiments.

Morphological variation may also impact or influence community structure. Gatz [5] described resource utilization within an assemblage of freshwater stream fishes on the basis of their associated morphologies. He discerned similar morphological patterns among disparate assemblages indicating non-random distribution of resource niche space. Gatz's [5] conclusion of non-random morphological assembly was supported by Winston [6] for Cyprinid shape, where a lack of morphological overlap was attributed to interspecific competition. This non-random distribution in morphological space within an assemblage could potentially result in large overall impacts following a shift in one or more taxa. Environmental alterations that induce a change in morphology and thus functional roles could instigate increased or relaxed competition, directly or indirectly.

\section{Conclusions}

Discerning linkages between morphology and hydrology has conservation applications for understanding the capacity of species to respond to changing ecosystems. The results presented herein provide a template for species that have persisted in a variety of sites over the past century. Given that these sites are disturbed and altered (as evidenced by the IHA analyses), future work should attempt to repeat this study with different taxa from less altered sites to test whether these species are successful solely because they are plastic in their morphologies. Morphological variation may also aid in understanding the invasion potential for ecosystems [72] through competition overlap and resilience. One prediction of the ecosystem resilience model is that competition among taxa of similar shape [6] can prevent invasive taxa from becoming established [73]. Linking variation in morphology via disparity indices with assemblage shifts could provide one avenue to address these sorts of questions by establishing a metric based on morphology that could be used to look at ecosystem level resilience. Morphological variation within communities is linked to the zoogeographical history of a region [32] and can be applied at a taxon specific level to better understand historic and current environmental conditions and biogeographical patterns. Understanding individual response mechanisms may increase understanding of selective pressures that influenced the evolutionary history of the Cyprinidae.

\section{Abbreviations \\ INHS: Illinois Natural History Survey; USGS: United States Geological Survey; IHA: indicators of hydrologic alteration; GPA: generalized procrustes analyses; RWA: relative warp analysis; MANCOVA: multivariate analysis of covariance; VIF: variance inflation factor.}

\section{Authors' contributions}

SJJ performed all analyses and writing and MP contributed to writing. Both authors read and approved the final manuscript.

\section{Author details \\ 1 Department of Biological Sciences, Dwyer Hall, Wright State University-Lake Campus, Celina, OH 45822, USA. ${ }^{2}$ Department of Biology, Aquatic Biology} and Fisheries Center, Ball State University, Muncie, IN 47306, USA.

\section{Acknowledgements}

We are grateful to the Illinois Natural History Survey for specimen loans and to Emily Brink (Schritter) for assistance in the laboratory.

\section{Competing interests}

The authors declare that they have no competing interests.

\section{Availability of data and material}

All data is available in Appendices and raw images of study specimens are available upon request.

Ethics approval and consent to participate

The study used previously collected museum specimens. No review board was required. Not applicable.

Funding

No funding was received to complete this study.

\section{Appendix}

See Tables 5, 6. 
Table 5 Lot numbers for preserved specimens from the Illinois Natural History Survey (INHS)

\begin{tabular}{|c|c|c|c|c|}
\hline Species & INHS & River & Year & $\begin{array}{l}\text { Illinois } \\
\text { county }\end{array}$ \\
\hline Luxilus chrysocephalus & 8513 & Sangamon River & 1965 & Piatt \\
\hline Luxilus chrysocephalus & 16093 & Sangamon River & 1965 & Macon \\
\hline Luxilus chrysocephalus & 21385 & Sangamon River & 1968 & McLean \\
\hline Luxilus chrysocephalus & 43181 & Sangamon River & 1989 & Champaign \\
\hline Luxilus chrysocephalus & 84335 & Sangamon River & 1901 & Champaign \\
\hline Luxilus chrysocephalus & 84370 & Sangamon River & 1901 & Champaign \\
\hline Luxilus chrysocephalus & 84385 & Sangamon River & 1901 & Champaign \\
\hline Luxilus chrysocephalus & 91871 & Sangamon River & 2001 & Champaign \\
\hline Luxilus chrysocephalus & 96038 & Sangamon River & 1988 & Champaign \\
\hline Luxilus chrysocephalus & 96063 & Sangamon River & 1987 & Champaign \\
\hline Luxilus chrysocephalus & 98050 & Sangamon River & 1988 & Champaign \\
\hline Lythrurus umbratilis & 11950 & Little Vermilion & 1962 & Vermilion \\
\hline Lythrurus umbratilis & 32769 & Little Vermilion & 1994 & Vermilion \\
\hline Lythrurus umbratilis & 37727 & Little Vermilion & 1996 & Vermilion \\
\hline Lythrurus umbratilis & 41540 & Little Vermilion & 1997 & Vermilion \\
\hline Lythrurus umbratilis & 42177 & Little Vermilion & 1997 & Vermilion \\
\hline Lythrurus umbratilis & 43139 & Little Vermilion & 1997 & Vermilion \\
\hline Lythrurus umbratilis & 65032 & Little Vermilion & 1989 & Vermilion \\
\hline Lythrurus umbratilis & 86476 & Little Vermilion & 1899 & Vermilion \\
\hline Lythrurus umbratilis & 94588 & Little Vermilion & 2002 & Vermilion \\
\hline Notropis atherinoides & 632 & Lake Michigan & 1964 & Cook \\
\hline Notropis atherinoides & 25287 & Illinois River & 1957 & Grundy \\
\hline Notropis atherinoides & 25460 & Illinois River & 1962 & LaSalle \\
\hline Notropis atherinoides & 25480 & Illinois River & 1963 & LaSalle \\
\hline Notropis atherinoides & 26591 & Lake Michigan & 1975 & Cook \\
\hline Notropis atherinoides & 27303 & Lake Michigan & 1979 & Lake \\
\hline Notropis atherinoides & 49876 & Illinois River & 1997 & Grundy \\
\hline Notropis atherinoides & 51058 & Illinois River & 1902 & LaSalle \\
\hline Notropis atherinoides & 51173 & Lake Michigan & 1998 & Cook \\
\hline Notropis atherinoides & 52188 & Illinois River & 1999 & LaSalle \\
\hline Notropis atherinoides & 53920 & Lake Michigan & 1999 & Cook \\
\hline Notropis atherinoides & 84565 & Lake Michigan & 1900 & Cook \\
\hline Notropis atherinoides & 85583 & Illinois River & 1897 & Mason \\
\hline Notropis atherinoides & 98018 & Illinois River & 2003 & LaSalle \\
\hline Notropis stramineus & 8022 & Sangamon River & 1959 & Champaign \\
\hline Notropis stramineus & 10902 & Mackinaw River & 1958 & Woodford \\
\hline Notropis stramineus & 14879 & Mackinaw River & 1963 & Tazewell \\
\hline Notropis stramineus & 15063 & Mackinaw River & 1966 & Tazewell \\
\hline Notropis stramineus & 16134 & Sangamon River & 1968 & Macon \\
\hline Notropis stramineus & 21240 & Sangamon River & 1965 & McLean \\
\hline Notropis stramineus & 33080 & Mackinaw River & 1994 & Woodford \\
\hline Notropis stramineus & 40803 & Mackinaw River & 1995 & Tazewell \\
\hline Notropis stramineus & 41475 & Mackinaw River & 1997 & Tazewell \\
\hline Notropis stramineus & 42050 & Mackinaw River & 1996 & Tazewell \\
\hline Notropis stramineus & 42188 & Sangamon River & 1997 & Champaign \\
\hline Notropis stramineus & 52941 & Mackinaw River & 1999 & Woodford \\
\hline Notropis stramineus & 57216 & Sangamon River & 2000 & Macon \\
\hline Notropis stramineus & 84387 & Sangamon River & 1901 & Champaign \\
\hline
\end{tabular}

Table 5 continued

\begin{tabular}{|c|c|c|c|c|}
\hline Species & INHS & River & Year & $\begin{array}{l}\text { Illinois } \\
\text { county }\end{array}$ \\
\hline Notropis stramineus & 85832 & Mackinaw River & 1901 & McLean \\
\hline Notropis stramineus & 93187 & Mackinaw River & 2000 & McLean \\
\hline Notropis stramineus & 93223 & Mackinaw River & 2000 & McLean \\
\hline Notropis stramineus & 96042 & Sangamon River & 1988 & Champaign \\
\hline Notropis stramineus & 99815 & Sangamon River & 2003 & Champaign \\
\hline Notropis stramineus & 101741 & Sangamon River & 2005 & Macon \\
\hline Pimephales notatus & 617 & Lake Michigan & 1964 & Cook \\
\hline Pimephales notatus & 13714 & Salt Creek & 1963 & DeWitt \\
\hline Pimephales notatus & 13731 & Salt Creek & 1967 & DeWitt \\
\hline Pimephales notatus & 18681 & Salt Creek & 1971 & Logan \\
\hline Pimephales notatus & 42450 & Salt Creek & 1997 & DeWitt \\
\hline Pimephales notatus & 42834 & Salt Creek & 1997 & Logan \\
\hline Pimephales notatus & 56877 & Lake Michigan & 1980 & Cook \\
\hline Pimephales notatus & 84567 & Lake Michigan & 1900 & Cook \\
\hline Pimephales notatus & 85438 & Salt Creek & 1900 & Logan \\
\hline Pimephales notatus & 85460 & Salt Creek & 1901 & Logan \\
\hline Pimephales notatus & 89383 & Salt Creek & 2000 & Mason \\
\hline Pimephales notatus & 96955 & Lake Michigan & 1999 & Cook \\
\hline Pimephales notatus & 96960 & Lake Michigan & 1998 & Cook \\
\hline Pimephales notatus & 97146 & Lake Michigan & 1987 & Cook \\
\hline Pimephales notatus & 97588 & Salt Creek & 2003 & Mason \\
\hline
\end{tabular}


Table 6 Results from IHA analyses with time

\begin{tabular}{|c|c|c|c|c|c|c|c|c|c|c|c|}
\hline \multirow[t]{2}{*}{ Variable } & \multirow[t]{2}{*}{ IHA category } & \multicolumn{2}{|c|}{ Illinois River } & \multicolumn{2}{|c|}{$\begin{array}{l}\text { Mackinaw } \\
\text { River }\end{array}$} & \multicolumn{2}{|c|}{ Salt Creek } & \multicolumn{2}{|c|}{$\begin{array}{l}\text { Sangamon } \\
\text { River }\end{array}$} & \multicolumn{2}{|c|}{$\begin{array}{l}\text { Vermillion } \\
\text { River }\end{array}$} \\
\hline & & Slope & $\mathrm{R}^{2}$ & Slope & $R^{2}$ & Slope & $\mathrm{R}^{2}$ & Slope & $\mathrm{R}^{2}$ & Slope & $\mathrm{R}^{2}$ \\
\hline High pulse count & Frequency and duration of pulses & 0.03 & 0.05 & -0.07 & 0.18 & -0.02 & 0.02 & 0.03 & 0.07 & 0.05 & 0.1 \\
\hline High pulse duration & & -0.02 & 0.01 & 0.15 & 0.06 & 0.14 & 0.09 & 0.07 & 0.04 & -0.01 & 0.01 \\
\hline Low pulse count & & 0.16 & 0.19 & 0 & 0 & 0.01 & 0 & 0 & 0 & 0.01 & 0.01 \\
\hline Low pulse duration & & 0.04 & 0.07 & -0.05 & 0.01 & -0.1 & 0.01 & -0.62 & 0.08 & -0.19 & 0.09 \\
\hline 1-day maximum & Magnitude and duration of annual extremes & 295.2 & 0.15 & -15.08 & 0 & 21.41 & 0 & 129.6 & 0.04 & 81.05 & 0.06 \\
\hline 1-day minimum & & -61.55 & 0.51 & -0.1 & 0.02 & 0.84 & 0.12 & 1.74 & 0.07 & 0.44 & 0.18 \\
\hline 30-day maximum & & 58.76 & 0.05 & 2.91 & 0 & 21.19 & 0.03 & 58.36 & 0.06 & 17.57 & 0.07 \\
\hline 30-day minimum & & -65.06 & 0.49 & -0.4 & 0.05 & 1.31 & 0.1 & 0.48 & 0 & 0.75 & 0.13 \\
\hline 3-day maximum & & 241.7 & 0.14 & -1.38 & 0 & 21.84 & 0 & 122.8 & 0.04 & 65.77 & 0.07 \\
\hline 3-day minimum & & -63.79 & 0.55 & -0.12 & 0.02 & 0.80 & 0.11 & 1.62 & 0.06 & 0.46 & 0.18 \\
\hline 7-day maximum & & 168.40 & 0.12 & -0.08 & 0 & 18.83 & 0 & 101.8 & 0.05 & 37.48 & 0.06 \\
\hline 7-day minimum & & -64.05 & 0.55 & -0.12 & 0.02 & 0.99 & 0.12 & 1.51 & 0.04 & 0.48 & 0.17 \\
\hline 90-day maximum & & 6.55 & 0.00 & 1.4 & 0 & 13.7 & 0.04 & 33.14 & 0.05 & 10.19 & 0.08 \\
\hline 90-day minimum & & -51.73 & 0.29 & -0.09 & 0 & 1.73 & 0.01 & 4.17 & 0.02 & 3.02 & 0.06 \\
\hline Baseflow index & & 0 & 0.56 & 0 & 0.01 & 0 & 0.03 & 0 & 0.02 & 0 & 0.06 \\
\hline April & Magnitude of monthly conditions & -38.09 & 0.02 & -4.48 & 0.02 & 2.82 & 0 & -1.15 & 0 & 5.77 & 0.03 \\
\hline August & & -41.95 & 0.17 & 1.29 & 0.03 & 6.62 & 0.03 & -9.85 & 0.01 & 2.21 & 0.02 \\
\hline December & & -42.04 & 0.06 & -1.51 & 0.01 & 9.13 & 0.03 & 31.28 & 0.08 & 6.32 & 0.06 \\
\hline February & & -39.67 & 0.05 & -3.34 & 0.02 & 3.78 & 0 & 14.22 & 0.01 & 3.02 & 0.01 \\
\hline January & & -61.71 & 0.11 & -1.32 & 0 & 0.36 & 0 & 4.07 & 0 & -5.45 & 0.02 \\
\hline July & & -11.87 & 0.01 & 2.99 & 0.03 & 4.49 & 0.01 & -1.19 & 0 & 3.07 & 0.02 \\
\hline June & & 3.09 & 0.00 & 4.72 & 0.07 & 10.42 & 0.03 & 13.86 & 0.01 & 4.24 & 0.03 \\
\hline March & & -18.53 & 0.01 & 1.18 & 0 & 19.43 & 0.06 & 27.55 & 0.04 & 8.99 & 0.07 \\
\hline May & & -25.76 & 0.02 & 7.83 & 0.04 & 17.66 & 0.04 & 29.63 & 0.03 & 4.31 & 0.01 \\
\hline November & & -51.93 & 0.10 & -0.78 & 0 & 2.28 & 0 & 10.67 & 0.02 & 6.26 & 0.05 \\
\hline October & & -52.70 & 0.13 & -1.31 & 0.01 & 4.14 & 0.01 & -0.31 & 0 & 3.48 & 0.05 \\
\hline September & & -38.86 & 0.07 & 0.41 & 0 & 5.15 & 0.04 & -12.2 & 0.02 & 1.49 & 0.01 \\
\hline Fall rate & Rate and frequency of water condition changes & -3.67 & 0.18 & 0.07 & 0 & -0.11 & 0 & -0.32 & 0.01 & -0.37 & 0.08 \\
\hline Number of reversals & & 0.47 & 0.11 & 0.12 & 0.03 & 0.12 & 0.03 & 0.52 & 0.41 & 0.36 & 0.17 \\
\hline Rise rate & & 1.98 & 0.05 & -0.54 & 0.02 & -0.13 & 0 & -0.15 & 0 & 0.47 & 0.02 \\
\hline Date of maximum & Timing of annual extreme conditions & 0.47 & 0.02 & 0.4 & 0.02 & 1.07 & 0.07 & -0.06 & 0 & 0.19 & 0 \\
\hline Date of minimum & & 0.92 & 0.05 & -0.02 & 0 & -0.1 & 0 & 0.43 & 0.02 & -0.08 & 0 \\
\hline
\end{tabular}

See Tables 1 and 2 for site descriptions. Significant $(P<0.05)$ slope values are in italic

Received: 13 August 2016 Accepted: 13 October 2016

Published online: 20 October 2016

\section{References}

1. Poff NL, Allan JD, Bain MB, Karr JR, Prestegaard KL, Richter BD, Sparks RE, Stromberg JC. The natural flow regime. Bioscience. 1997;47:769-84.

2. Richter BD, Braun DP, Mendelson MA, Master LL. Threats to imperiled freshwater fauna. Conserv Biol. 1997;11:1081-93.

3. Xenopoulos MA, Lodge DM. Going with the flow: using speciesdischarge relationships to forecast losses in fish biodiversity. Ecology. 2006;87:1907-14

4. Ross ST, Matthews WJ, Echelle AA. Persistence of stream fish assemblages: effects of environmental change. Am Nat. 1985;126:24-40.
5. Gatz AJ. Community organization in fishes as indicated by morphological features. Ecology. 1979;60:711-8.

6. Winston MR. Co-occurrence of morphologically similar species of stream fishes. Am Nat. 1995; 145:527-45.

7. Tilman D, Knops J, Wedin D, Reich P, Ritchie M, Siemann E. The influence of functional diversity and composition on ecosystem processes. Science. 1997:277:1300-2.

8. Wainwright PC, Reilly SM. Ecological morphology: integral organismal biology. Chicago: University of Chicago Press; 1994.

9. Eklöv P, Svanbäck R. Predation risk influences adaptive morphological variation in fish populations. Am Nat. 2006;167:440-52.

10. Van Valen L. Morphological variation and width of ecological niche. Am Nat. 1965:99:377-90.

11. Langerhans RB. Predictability of phenotypic differentiation across flow regimes in fishes. Integr Comp Biol. 2008;158:699-708. 
12. Hood CS, Heins DC. Ontogeny and allometry of body shape in the blacktail shiner, Cyprinella venusta. Copeia. 2000;2000:270-5.

13. Svanbäck R, Eklöv P. Effects of habitat and food resources on morphology and ontogenetic growth trajectories in perch. Oecologia. 2002;131:61-70

14. Jacquemin SJ, Martin E, Pyron M. Morphology of bluntnose minnow Pimephales notatus (Cyprinidae) covaries with habitat in a central Indiana watershed. Am Midl Nat. 2013;169:137-46.

15. Langerhans RB, Layman CA, Langerhans AK, Dewitt TJ. Habitat-associated morphological divergence in two Neotropical fish species. Biol J Linn Soc. 2003;80:689-98.

16. Haas TC, Blum MJ, Heins DC. Morphological responses of a stream fish to water impoundment. Biol Lett. 2010;6:803-6.

17. Dugas MB, Franssen NR, Bastille MO, Martin RA. Morphological correlates of river velocity and reproductive development in an ornamented stream fish. Evol Biol Fish. 2016;30:21-33.

18. Pakkasmaa S, Piironen J. Water velocity shapes juvenile salmonids. Evol Ecol. 2001;14:721-30.

19. Cureton JC II, Broughton RE. Rapid morphological divergence of a stream fish in response to changes in water flow. Biol Lett. 2014;10:20140352.

20. Forbes SA, Richardson RE. The Fishes of Illinois. Urbana: Illinois State Laboratory of Natural History; 1908.

21. Smith PW. The Fishes of Illinois. Champaign: University of Illinois Press; 1979.

22. Pyke GH, Ehrlich PR. Biological collections and ecological/environmenta research: a review, some observations and a look to the future. Biol Rev. 2010;85:247-66.

23. Ficke $A D$, Myrick CA, Hansen $\sqcup$. Potential impacts of global climate change on freshwater fisheries. Rev Fish Biol Fish. 2007;17:581-613.

24. Harris NM, Gurnell AM, Hannah DM, Petts GE. Classification of river regimes: a context for hydroecology. Hydrol Process. 2000;14:2831-48.

25. Poff NL, Zimmerman KH. Ecological responses to altered flow regimes: a literature review to inform the science and management of environmental flows. Freshw Biol. 2010:55:194-205.

26. Haas TC, Heins DC, Blum MJ. Predictors of body shape among populations of a stream fish (Cyprinella venusta, Cypriniformes: Cyprinidae). Biol J Linn Soc. 2015;115:842-58.

27. Dewson ZS, James ABW, Death RG. A review of the consequences of decreased flow for instream habitat and macroinvertebrates. J N Am Benthol Soc. 2007;26:401-15.

28. Taylor CM, Millican DS, Roberts ME, Slack WT. Long-term change to fish assemblages and the flow regime in a southeastern US river system after extensive aquatic ecosystem fragmentation. Ecography. 2008;31:1-11.

29. Johnson PTJ, Olden JD, Vander Zanden MJ. Dam invaders: impoundments facilitate biological invasions into freshwaters. Front Ecol Environ. 2008;6:357-63.

30. Poff NL, Allan JD. Functional organization of stream fish assemblages in relation to hydrologic variability. Ecology. 1995;76:606-27.

31. Pyron M, Lauer TE. Hydrological variation and fish assemblage structure in the middle Wabash River. Hydrobiologia. 2004;525:203-13.

32. Hoagstrom CW, Berry CR. Morphological diversity among fishes in a Great Plains river drainage. Hydrobiologia. 2008;596:367-86.

33. Webb M, Reid M, Thoms M. The influence of hydrology and physical habitat character on fish assemblages at different temporal scales. River Syst. 2011;19:283-99.

34. Koel TM, Sparks RE. Historical patterns of river stage and fish communities as criteria for operations of dams on the Illinois River. River Res Appl. 2002:18:3-19.

35. Rohlf FJ. tpsDig - thin plate spline digitizer, version 2.11. Stony Brook: State University of New York at Stony Brook; 2001.

36. Rohlf FJ. tpsUtil - thin plate spline utility program, version 1.46. Stony Brook: State University of New York at Stony Brook; 2010.

37. Zelditch ML, Swiderski DL, Sheets HD. Geometric morphometrics for biologists: a primer. Cambridge: Elsevier Academic Press; 2004.

38. Jawad LA. The effect of formalin, alcohol and freezing on some body proportions of Alepes djeddaba (Pisces: Carangidae) collected from the Red Sea coast of Yemen. Rev Biol Mar Oceanogr. 2003:38:77-80.

39. Richter BD, Baumgartner JV, Powell J, Braun DP. A method for assessing hydrologic alteration within ecosystems. Conserv Biol. 1996;10:1163-74.

40. Chapra SC, Dove A, Warren GJ. Long-term trends of Great Lakes major ion chemistry. J Great Lakes Res. 2012;38:550-60.
41. Rohlf FJ. In: Marcus LF, Bello E, Garcia-Valdecasa AG, editors. Contributions to morphometrics. Madrid: Museo Nacional de Ciencias Naturales; 1993. p. $131-59$.

42. Sheets HD, Zelditch ML. Studying ontogenetic trajectories using resampling methods and landmark data. Hystrix. 2013;24:67-73.

43. Scheiner SM. In: Scheiner SM, Gurevitch J, editors. Design and analysis of ecological experiments 2nd edition. Oxford: Oxford University Press; 2001 p. 99-115.

44. Nakazawa M. fmsb: functions for medical statistics book with some demographic data. R package version 0.5.2. 2015. http://CRAN.R-project. $\mathrm{org} /$ package $=$ fmsb. Accessed Mar 2016

45. Fox J, Friendly M, Monette G. Heplots: visualizing tests in multivariate linear models. R package version 1.0-0. 2012. http://CRAN.R-project.org/ package $=$ heplots. Accessed Mar 2016

46. Collar DC, Near TJ, Wainwright PC. Comparative analysis of morphological diversity: does disparity accumulate at the same rate in two lineages of centrarchid fishes? Evolution. 2005;59:1783-94.

47. Friedman M. Explosive morphological diversification of spiny-finned teleost fishes in the aftermath of the end-cretaceous extinction. Proc $R$ Soc B. 2010. doi:10.1098/rspb.2009.2177.

48. Adams D, Collyer M, Kaliontzopoulou A, Sherratt E. Geomorph: geometric morphometric analyses of 2D/3D landmark data. R package version 3.0.1. 2016. http://CRAN.R-project.org/package=geomorph. Accessed July 2016.

49. Querino RB, Moraes RCB, Zucchi RA. Relative warp analysis to study morphological variation in the genital capsule of Trichogramma pretiosum Riley (Hymenoptera: Trichogrammatidae). Neotrop Entomol. 2002:31:217-24

50. Rohlf FJ. tpsRegr-thin plate splines regression analysis, version 1.43. Stony Brook: State University of New York at Stony Brook; 2016.

51. Rincón PA, Bastir M, Grossman GD. Form and performance: body shape and pre-capture success in four drift-feeding minnows. Oecologia. 2007;152:345-55.

52. Hedrick AV Temeles EJ. The evolution of sexual dimorphism in animals: hypotheses and tests. Trends Ecol Evol. 1989;4:136-8.

53. Parker GA. The evolution of sexual size dimorphism in fish. J Fish Biol. 1992;41(Supplement B):1-20.

54. Ostrand KG, Wilde GR, Strauss RE, Young RR. Sexual dimorphism in plains minnow, Hybognathus placitus. Copeia. 2001;2001:563-5.

55. Skelton CE. New dace of the genus Phoxinus (Cyprinidae: Cypriniformes) from the Tennessee River Drainage, Tennessee. Copeia. 2001;2001:118-28.

56. Pyron M, Fincel M, Dang M. Sexual size dimorphism and ecomorphology of spotfin shiner (Cyprinella spiloptera) from the Wabash River watershed. J Freshw Ecol. 2007;22:687-96.

57. Douglas ME. Analysis of sexual dimorphism in an endangered cyprinid fish (Gila cypha Miller) using video image technology. Copeia. 1993;1993:334-43.

58. Chakraborty A, Sakai M, Iwatsuki Y. Museum fish specimens and molecular taxonomy: a comparative study on DNA extraction protocols and preservation techniques. J Appl Ichthyol. 2006;22:160-6.

59. Vogel S. Life in moving fluids: the physical biology of flow. 2nd ed. Princeton: Princeton University Press; 1994.

60. Hart JS. Geographical variation of some physiological and morphological characters in certain freshwater fish. Univ Toronto Stud Biol Ser 60 1952;72:1-79.

61. Schmitt RJ, Holbrook SJ. Ontogeny of prey selection by black surfperch Embiotoca jacksoni (Pisces: Embiotocidae): the roles of fish morphology, foraging behavior, and patch selection. Mar Ecol. 1984;18:225-39.

62. Meyer A. Phenotypic plasticity and heterochrony in Cichlasoma manaquense (Pisces, Chichlidae) and their implications for speciation in cichlid fishes. Evolution. 1987:41:1357-69.

63. Laurent P, Perry SF. Environmental effects on gill morphology. Physiol Zool. 1991;64:4-25.

64. Schluter D. Experimental evidence that competition promotes divergence in adaptive radiation. Science. 1994;266:798-801.

65. Hegrenes S. Diet-induced phenotypic plasticity of feeding morphology in the orangespotted sunfish, Lepomis humilis. Ecol Freshw Fish. 2001;10:35-42

66. Langerhans RB, Makowicz AM. Shared and unique features of morphological differentiation between predator regimes in Gambusia caymanensis. J Evol Biol. 2009:22:2231-42. 
67. Lessios HA, Weinberg JR, Starczak VR. Temporal variation in populations of the marine isopod Excirolana: how stable are gene frequencies and morphology? Evolution. 1994;48:549-63.

68. Hjelm J, Weerd GH, Sibbing FA. Functional link between foraging performance, functional morphology, and diet shift in roach (Rutilus rutilus). Can J Fish Aquat Sci. 2003;60:700-9.

69. Ruehl CB, DeWitt TJ. Trophic plasticity and foraging performance in red drum, Sciaenops ocellatus (Linnaeus). J Exp Mar Biol Ecol. 2007;349:284-94.

70. Ellers J. In: Verhoef HA, Morin PJ, editors. Community ecology: processes, models, and applications. Oxford: Oxford University Press; 2010. p. $151-62$.
71. Loreau M, Naeem S, Inchausti P, Bengtsson J, Grime JP, Hector A, Hooper DU, Huston MA, Raffaelli D, Schmid B, Tilman D, Wardle DA. Biodiversity and ecosystem functioning: current knowledge and future challenges. Science. 2001;294:804-8.

72. Wanink JH, Witte F. Rapid morphological changes following niche shift in the zooplanktivorous cyprinid Rastrineobola argentea from Lake Victoria. Neth J Zool. 2000;50:365-72.

73. Mason NWH, Mouillot D, Lee WG, Wilson JB. Functional richness, functional evenness and functional divergence: the primary components of functional diversity. Oikos. 2005;111:112-8.

\section{Submit your next manuscript to BioMed Central and we will help you at every step:}

- We accept pre-submission inquiries

- Our selector tool helps you to find the most relevant journal

- We provide round the clock customer support

- Convenient online submission

- Thorough peer review

- Inclusion in PubMed and all major indexing services

- Maximum visibility for your research

Submit your manuscript at www.biomedcentral com/submit 